\title{
Menkes' Kinky Hair Syndrome: Studies of Copper Metabolism and Long Term Copper Therapy
}

\author{
D. M. WILLIAMS, ${ }^{(20)}$ C. L. ATKIN, D. B. FRENS, AND P. F. BRAY \\ Department of Internal Medicine and Division of Pediatric Neurology of the Departments of Pediatrics and \\ Neurology. University of Utah College of Medicine, Salt Lake City, Utah. USA
}

\begin{abstract}
Summary
A patient with Menkes' kinky hair syndrome was treated with oral CuSO, . Plasma copper, ceruloplasmin, red cell copper, and 24-hr urine copper excretion remained essentially unchanged. Intravenous copper infusion resulted in a rise of serum ceruloplasmin. During administration of a test meal of " $\mathrm{lit} \mathrm{Cu}\left(\mathrm{NO} \mathrm{O}_{3}\right)_{2}$, the patient was given alternately a volume of $0.9 \% \mathrm{NaCl}$ or an equal volume of plasma intravenously. Radioactivity found in the blood was unchanged after each infusion period. During $\mathbf{4 2 7}$ days of subcutaneous copper, plasma p-phenylenediamine oxidase activity and plasma copper rose toward normal. Subsequent balance studies showed that the patient was in negative copper balance because of large losses in feces. Scanning electron microscopy demonstrated persistent pili torti.
\end{abstract}

\section{Speculation}

Menkes kinky hair syndrome is probably due to a generalized defect in a copper-binding protein that results in increased gastrointestinal copper loss and persistent abnormalities of hair in the copper-replete patient.

Menkes' kinky hair syndrome (MKHS) is an X-linked recessive disorder characterized by abnormaltities of hair (pili torti or twisted hairs), bones, and arteries, ats well as by seizures, progresssive developmental deterioration, and death usually before the age of 2 years (11). The similarities between this clinical syndrome and the manifestations of nutritional copper deficiency in "sway-back" sheep led Danks and his coworkers (5) to their observations that copper metabolism was abnormal in patients with MKHS. This abnormality is most clearly reflected in very low levels of plasma copper and ceruloplasmin but is unlike that seen in experimental copper deficiency in that red cell copper is normal, and anemia and leukopenia are absent (4). Mucosal transport of copper appears to be defective in MKIIS, and parenteral therapy can be used to circumvent this defect $(1,4)$. Intravenous copper therapy, although effective in raising the levels of plasma copper and ceruloplasmin, and reportedly of some clinical bencfit, is cumbersome for long term use.

The purposes of these studies were to gain additional understanding of the nature of the defeet in MKIIS and to assess the effects of long term therapy with subcutaneous copper.

\section{CASE REPOR'I}

This male infant (UUMC $30-58-82$ ) was the $1.560 \mathrm{~g}$ (small-forgestational age) product of a full term first pregnancy and uncomplicated delivery. Both parents were in good health without history of neurologic discase. At + months of age the patient began to have frequent seizures which were characterized by blinking of the eyclids, asynchronous jerking of the extremities, crying, and drooling. His height, woight, and head circumfer- ence were below the third percentile and developmental milestones were markedly delayed. His hair was light in color and very short. Visual fixation and response to light were absent. Muscle tone was universally decreased, but deep tendon reflexes were uniformly brisk, and sustained ankle clonus was present bilaterally. Serum electrolytes, pH, glucose, calcium, magnesium, zinc, hepatic and renal function tests, urine and serum amino acid chromatography, urinalysis, cerebrospinal fluid, and skull films were normal. Hematologic studies revealed volume of packed red cells, 36" ; reticulocyte count, $4.0 \%$; white blood cells, $7,20\left(0 / \mathrm{mm}^{3}\right.$; and platelets, $450.000 / \mathrm{mm}^{3}$. Electroencephalograms demonstrated diffuse spike discharges. Minimal dilatation of both lateral ventricles was found by pneumonencephalogram, and marked tortuosity of all the intracranial branches of the right internal carotid artery was noted by arteriography. A possible fracture of the right eighth rib was seen on chest $x$-ray. Radiologic steletal survey revealed multiple metaphyseal avulsion fractures. Microscopic examination of the child's hair showed pili torti. Bone marrow examination was normal for age. Distinctly reduced values for plasma copper and ceruloplasmin were found, but red cell copper and superoxide dismutase (SOI)) and urine copper were not decreased (Table 1).

After partial seizure control was achieved with phenobarbital and diazepam, further investigative studies were undertaken following the approval of the Medical Isotopes and Human Research Committees and with the informed consent of the patient's parents.

\section{MATLRIALS AND MITHIODS}

\section{ANALYTIC METHODS}

Blood for copper studies was drawn with heparinized plastic syringes. Hematologic determinations were carried out by standard methods (2). Bile was aspirated from a nasoduodenal tube placed under fluoroscopic observation. Saline-washed red cells, plasma, urine, and other fluids were stored in specially cleaned glassware. Plasma iron, red cell, urine, bile, and stool copper values were determined by flame atomic absorption spectrophotometry (9). Plasma ('u was determined in $5-\mu 1$ aliquots in a Perkin-FImer IIGA-2000 graphite furnace. Plasma ceruloplasmin was measured by the p-phenylenediamine oxidase method of Ravin (13). Ceruloplasmin $\mathrm{Cu}$ was calculated assuming molecular weight as 134.000 and 6 (u atoms/ceruloplasmin molecule (14). Superoxide dismutase was determined by the method of McCord and Fridovich (10).

When a radioactive test meal was given, blood samples were collected before and after the meal. Red cells were washed twice in cold $0.15 \mathrm{M} \mathrm{NaCl}$ and resuspended in $0.15 \mathrm{M} \mathrm{NaCl}$. Aliquots of plasma and red cell suspension were counted in a Nuclear Chicago gamma well counter, model 8725 . All counts were corrected for background and for isotope decay. 


\section{PREPARATION OF COPPER FOR INJECTION}

Sterile $\mathrm{NaHCO}_{3}$-neutralized solution was prepared to contain $23 \mathrm{mM} \mathrm{CuCl} .2(1.450 \mu \mathrm{g} \mathrm{Cu} / \mathrm{ml}), 57.5 \mathrm{mMl}$ L-histidine, and $0.9{ }^{\circ} \mathrm{NaCl}$. Amino acid mixtures were unsuitable chelators because some $\mathrm{Cu}(\mathrm{II})$-amino acid complexes precipitated. Furthermore, commercial amino acids for parenteral administration contain $\mathrm{ISO}_{3}{ }^{-}$that was shown to give considerable reduction of $\mathrm{Cu}(\mathrm{II})$ to supposedly more toxic Cu(I).

Before use, all copper preparations were checked for sterility by culture and for absence of endotoxin by Limulus assays. Controls with added endotoxin showed that $\mathrm{Cu}(\mathrm{II})$-histidine complexes did not affect the assay.

For study by scimning electron microscopy, hair was cut as close to the scalp as possible. The proximal end was oriented, and the samples were examined in a Cambridge Stereoscan, Mark 2A scanning electron microscope.

\section{RIESULTS}

\section{FFFECT OF NORMAL PLASMA IN COPPER ABSORPTION}

Administration of oral copper supplementation failed o change baseline copper values, but intravenous copper given at two dose levels resulted in a rise of serum ceruloplasmin that was in good agreement with the observations of others (1). Therefore. to test the possibility that a missing plasma factor was required for copper absorption, additional studies were carried out using a test meal of "it $\mathrm{Cu}\left(\mathrm{NO}_{3}\right)_{2}$ ( New England Nuclear) added to soybean milk substitute. The test meal was given through a nasoduodenal tube at a constant rate of $50 \mathrm{ml} / \mathrm{hr}$ for 4 hr. During each of two study periods, the patient received 100 $\mu \mathrm{g} \mathrm{Cu}$ with 200$) \mu \mathrm{Ci}{ }^{64} \mathrm{Cu}$. During the first $2 \mathrm{hr}$ of the tube feeding, the patient was also given $0.9 \%^{\circ} \mathrm{NaCl}$ intravenously at a rate of $20 \mathrm{ml} / \mathrm{hr}$. Blood samples obtained at the end of the control infusion contained little radioactivity. Calculations based upon these levels, the patient's body weight volume of packed red cells (VPRC), and assumed blood volume of $0.75 \mathrm{dl} / \mathrm{kg}$.

Table 1. Copper and copper-containing proteins in patient with Menke's kinky hair syndrome' compared with normal value's

\begin{tabular}{lcc}
\hline & Normal range & Paticnt \\
\hline Plasma ceruloplasmin (mg/dl) & $19-36$ & 3 \\
Plasma copper $(\mu \mathrm{g} / \mathrm{dl})$ & $78-157$ & 15 \\
Red cell copper $(\mu \mathrm{g} / \mathrm{dl} \mathrm{RBC})$ & $63-107$ & 75 \\
Red cell superoxide dismutase (units/ml & $314-6.36$ & 857 \\
RBC) & & \\
Urinary copper excretion $(\mu \mathrm{g} / 24 \mathrm{hr})$ & $6-17$ & 8 \\
Bile copper $(\mu \mathrm{g} / \mathrm{dl})$ & $35-208$ & 28 \\
\hline
\end{tabular}

could account for no more than $0.2 \%$ of the administered dose. During the second $2 \mathrm{hr}$ of the feeding the patient was given a volume of his father's plasma intravenously at a rate of $20 \mathrm{ml} / \mathrm{hr}$, estimated to represent about $20 \%$ of the patient's blood volume; VPRC fell from $36 \%$ to $32 \%$. However, the ratdioactivity in the blood was unchanged from that observed during the saline infusion.

\section{EFIECT OF LONG TERM SUBCUTANEOUS COPPER TREATMIENT}

Daily injections of copper were administered subcutancously at alternate sites on the inner aspects of both thighs. These injections were begun 226 days after the patient's birth. Injection sites were inspected daily, and no evidence of hemolysis was found in blood samples.

The patient's course during 427 days of subcutancous copper treatment is shown in Figure 1. Throughout this time, the patient tolerated the injections well without local reaction or signs of copper toxicity. Both plasma ceruloplasmin and plasma copper rose progressively toward normal. However, normal levels of ceruloplasmin were not achieved until the patient had been treated for 65 days with quantities of copper some 2-7 times greater than the estimated normal requirement (16). During that time, the patient had received a total copper load of $30 \mathrm{mg}$ or approximately $4.3 \mathrm{mg} / \mathrm{kg}$. By comparison, copper concentration in the newborn has been estimated to be $4.7 \mathrm{mg} / \mathrm{kg}$ lean body mass (15). Urinary loss of copper increased during treatment. The loss of copper in urine when plasmat ceruloplasmin levels were stable corresponds to only about one-fourth the administered copper. However, increased urinary copper losses persisted even after copper treatment was discontinued, and plasma copper dropped to $54 \mu \mathrm{g} / \mathrm{dl}$.

Essentially all plasma copper could be accounted for by copper contained in ceruloplasmin except for two specimens received by mail (days 19(0. 240). Copper content of liver tissue obtained by percutaneous biopsy on day 209 was $38 \mu \mathrm{g} \mathrm{Cu} / \mathrm{g}$ wet weight. This compares with the average liver copper of $24 \mu \mathrm{g}$ $\mathrm{Cu} / \mathrm{g}$ wet weight (range 6.9-57.6 $\mu \mathrm{g} / \mathrm{g}$ ) in 25 infants varying in age from $0-2$ years of age (12).

\section{COPPER BAL.ANCE STUDIIS}

After the plasma ceruloplasmin had remained stable for approximately 2 months, the patient continued to receive daily injections of copper, $180 \mathrm{\mu g} / \mathrm{day}$, and was fed weighed aliquots of a standard homogenized dict. Copper content of food, urine, and stool was determined.

The results of 1.3 days of dietary balance studies (days 202215 in Fig. 1) are summarized in Table 2. The patient was clearly in negative copper balance, mainly because of large losses of

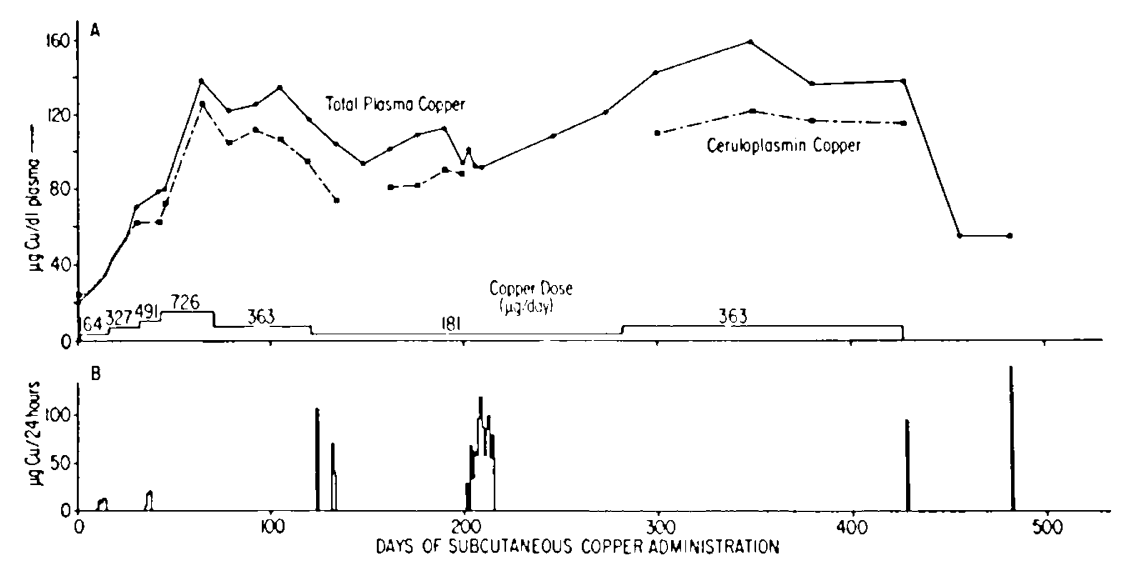

Fig. 1. A: the effect of subcutaneous copper administration on plasma copper $(\bullet-\bullet)$ and plasma ceruloplasmin copper ( $\square---[1)$ during the course of 427 days. Ceruloplasmin copper was calculated from measured $p$-phenylenediamine oxidase activity, the assumption of 6 atoms Cu/ molecule, and ceruloplasmin molecular weight of 134.000 . Some samples received by mail could not be adequately assayed for en/yme activity. Changes in dose levels of copper are noted across the bottom. B: the effect of subcutaneous copper administration on urinary copper excretion. Vertical bars represent total urinary copper excreted during 24 -hr intervals. 
Table 2. Copper balance studies during parenteral copper

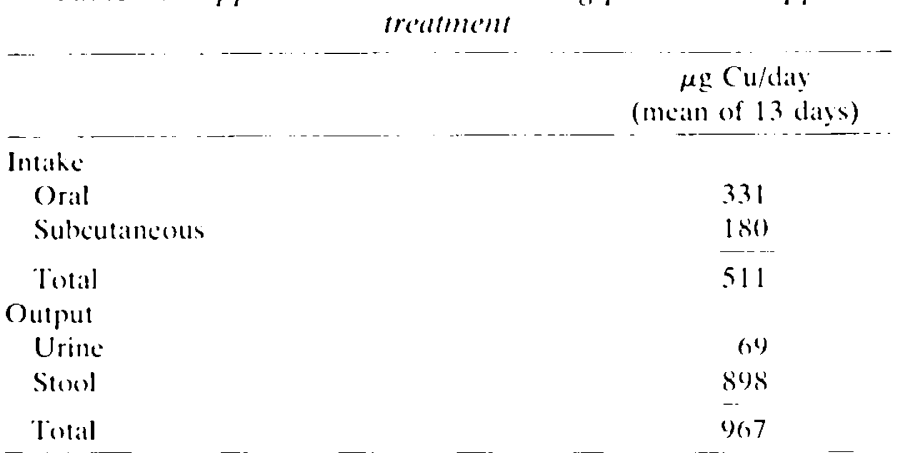

copper in feces. During the study, ceruloplasmin varied between $23.4 \mathrm{mg} / \mathrm{dl}$ and $18.6 \mathrm{mg} / \mathrm{dl}$ and plasma copper varied $90-105$ $\mu \mathrm{g} / \mathrm{dl}$. No bile was obtained.

\section{CLINICAL, COURSE}

During the prolonged period of subcutaneous copper therapy no changes occurred in the baby's somatic growth retardation, his clinical neurologic status, his $1: 1:$ (; or in ultramicroscopic appearance of his hair deformity (Fig. 2). The only evidence of clinical improvement was the radiographic disappearance of the metaphyseal avulsion fractures.

\section{I)IS( USSION}

Our patient demonstrated the typical clinical and laboratory features of Mentes hinky hair syndrome. These findlings have been remarkably constant in over to cases which have so far been described $(1,4,7,8,11)$. These changes have been interpreted to suggest that the manifestations of MKIS are the result of copper deficiency secondary to an absorptive defect. In our patient. we were unable to overeome this defect with oral copper supplementation.

One possible explanation for the decreased absorption of copper is an abonomality in or a decreased amount of a plasma acceptor substance. Albumin is the primary copper tramsport protein and its copper-binding sites have been characterized in several species (6). We were unable to demonstrate abmormalities of the patients albumin by several electrophoretic techniques. Also, infusion of the father's putatively normal plasma did not influence the absorption of radioactive copper. Nonetheless, these studies do not exclude the possibility that a plasma factor is missing in NKHS.

Our studies support the observations that the apparent mucosal block can be circumsented by the parenteral andministration of copper. Intratenous infusion of copper at two dose levels resulted in a rise in plasmal ceruloplasmin without evidence of acute toxicity. Intravenous copper treatment can be used to replete copper stores as shown by Grover and Scrutton (8). In our patient. copper replatement by the subcutancous route was managed easily, but amounts of copper several times greater than estimated normal requirements (16) were needed to maintain normal levels of plasmia copper and ceruloplasmin. In part. this appears to be due to increased copper excretion. Bile copper concentration was not increased during oral feeding of copper supplement or in the time immediately after intravenous infusion of copper, hut at a time when liver copper was within the normal range and plasma copper and ceruloplasmin appeared to be stable. copper losses. especially in the stool, excecded copper intake. It seems reasomable to propose that in addition to an absorptive defect. NKHS results in excessive copper loss due to a block in the reabsorption by the gastrointestinal mucosia of copper excreted in the bile. Alternatively, enteric secretion of copper occurs in normal humans (3), and this copper secretion may be increased or at least not reabsorbed in MKMLS. Our data
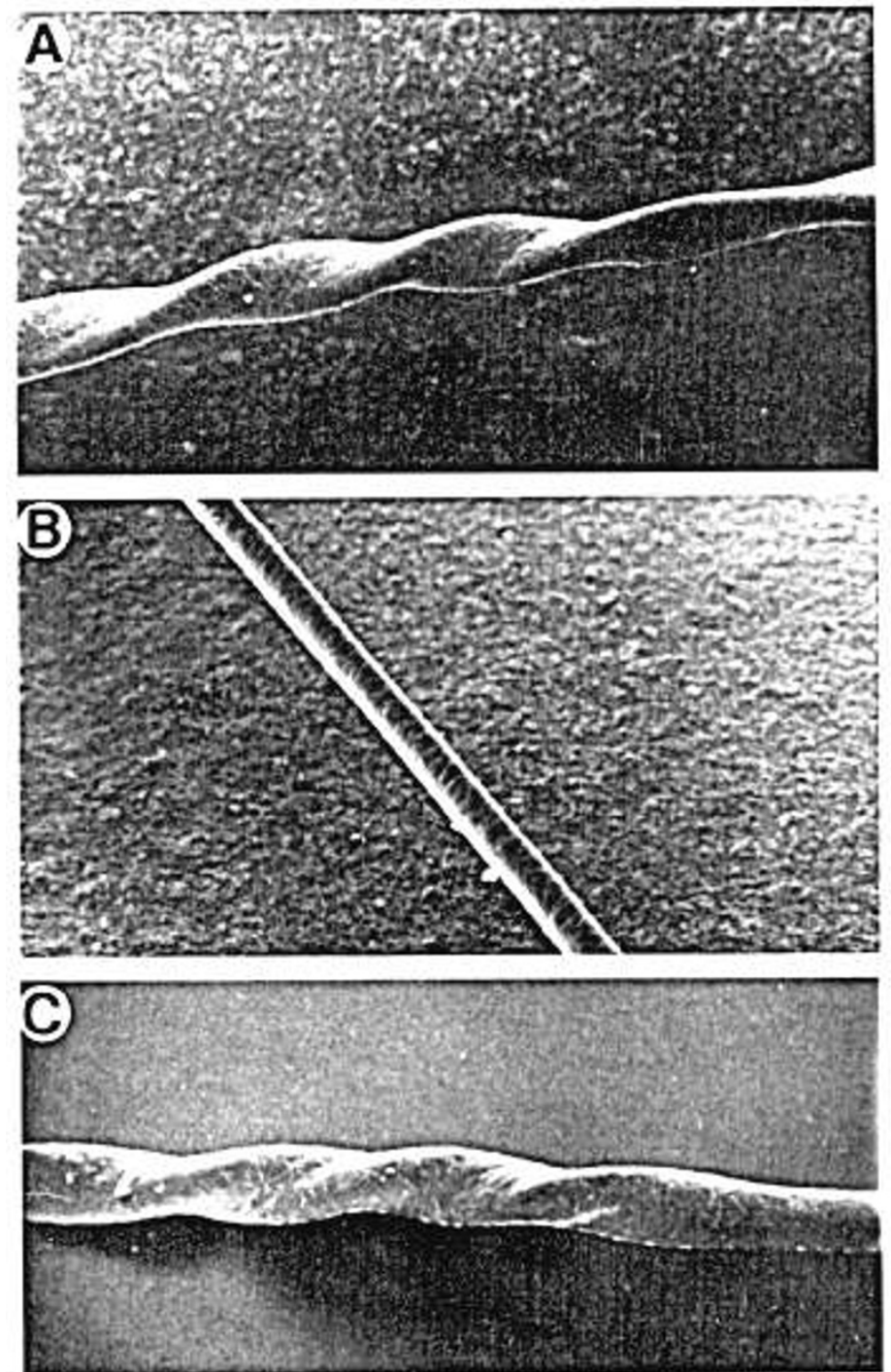

Fig. 2. Scanning electron photomicrographs $(\times 20()$ magnification $)$ of paticnt s hatir before copper administration (A) compared with a hatir of a male infant of similar age $(B)$ and the patient s hair after 5 months of subcutanceses copper administration (c). Scale-like plates or epicuticles are oberred and aid in orientation of hair shaft direction. Fhattening of the patient's hatir shaft is noted an well as twisting of the hatir around its central axis.

do net permit a resolution of these possibilities.

In contrast to the suggested improvement in the catse of Grover and Serutton (s). parenteral copper treatment did not bencfit our pattent clinically. The characteristic changes of the hair were present in our patient after 12 months of therapy whereas the changes seen in the wool of "sway-back" lambs are promptly reversed by copper therapy (15). Study of the possible role of special carrier proteins. such as metallothioncin (7) in copper metabolism seems warranted in paticnts with MKIS. and the careful measurement of copper-dependent enzymes in different oreans before and after treatment should be carried out.

\section{CONCLUSION}

Copper metabolism was studed in a 4 -month-old patient with the clinical manifestations of Menkes' kinky hair syndrome. As in other reported cases, the patient's plasma copper and ceruloplasmin levels were decreased. Oral copper did not alter levels of red cell copper, plasma copper, or ceruloplasmin. Intravenous infusion of normal plasma did not enhance absorption of copper 
from a radiolabeled test meal. However, increased ceruloplasmin was observed when copper was administered either intravenously or subcutaneously as $\mathrm{Cu}(\mathrm{II})$-L-histidine complex. Normal levels of plasma copper and ceruloplasmin were achieved after about 2 months of subcutancous copper treatment, but no measurable improvement in the patient's clinical condition occurred. Also, characteristic hair abnormalities persisted after 12 months of treatment. Copper loss, primarily in tie feces, exceeded copper intake at a time when plasma copper levels were stable. Plasma copper fell when subcutaneous copper was discontinued.

\section{REFERINCIS ANI NOTES}

1. Buchnall, W. E., Haslam, R. H. A., and Holtaman, N. A.: Kinky hair sydrome: Response to copper therapy. Pediatrics, $52: 653$ (1973)

2. Cartwright, G. E.: Diagnostic Laboratory Hematology, Ed. \& (Grunc \& Stratton. New York, 1968)

3. Carturight. G. 1:... and Wintrohe. M. M.: Copper metaboliom in normal subjects. Amer. J. Clin. Nutr., 14: 224 (1964).

4. Danki, D. M., Camphell, P. 1.., Stevens, B. J.. Masne, V., Cartwright, I:. Menkes kinky hair syndrome: An inherited defect in copper absorption with widespread effects. Pediatrics, 50: 188 (1972).

5. Danks, D. M.. Stevens, B. J., Camphell, P. E., Gillespic, J. M., WalkerSmith. J.. Blomfield, J., and Turner. B.: Menkes' kinky hair sindrome. Lancet, $1: 1100(1972)$

6. Dixon. J. W.., and Sarkar. B.: Isolation, amino acid sequence and copper (II)binding properties of peptide (1-24) of dog serum albumin. J. Biol. Chem. 241): $5872(1974)$.

7. Garnica, A. D.. Frios, J. L., Fasley, J. F., and Rennert, O. M.: Menhes net., 10: $149(197+)$.

8. Grover, W. D.. and Scrutton, M. C.: Copper infusion therapy in trichopoliodystrophy. J. Pediat., so: 216 (1975).

9. Gubler, C. J., lahey, M. E.. Ashenbrucher. H., Carturight, G. F., and Wintrobe, M. M.: Studies in copper metaholism. I. A method of the

Copyright "s 1977 International Pediatric Research Foundation. Inc. delermination of copper in whole blood, red blood cells, and plasma. J Biol. Chem.. 196: 209 (1952).

10. McCord, J. M., and Fridovich, I.: The reduction of eylochrome $c$ by milh xanthine oxidase. J. Biol. Chem., 273: 5753 (1968)

11. Menkes, J. H. Alter, M., Steigleder, G. K. Weikley, D. R., and Sung, J. H A sex-linked recessive disorder with retardation of growth, peculiar hair. and focal cercebral and cerebellar degeneration. Pediatrics, 29: 76.4 (1962).

12. Morrison, D. B. and Nash, T. P.. Jr.: The copper content of infane livers, $J$ Biol. Chem.. ss: 479 (193(1).

13. Ravin, H. A.: An improved colorimetric ensomatic assaly of ceruloplasmin. J Lat. Clin. Med., 58: 161 (1961).

14. Rydén, L., and Björk, 1.: A reinvestigation of some physico-hemical and chemical properties of human ceruloplasmin (ferroxidase). Biochemistry. 15: $3411(1976)$

15. Underwosd, E. J.: Trace Elements in Human and Animal Nutrition, Ed. 3. n. 57 (Academic Press, New York, 1971).

16. Wilson, J. F. and I ahey, M. I:. Failure to induce dietary deficiency of copper in premature infants. Pediatrics, 25: $40(1960)$.

17. We wish to thank Dr. (iarth Melers who referred the patient and Dr. Featnor Sutherland of the Wyoming State Training School. Lander. Wyoming, whe hats so kindly followed the patient in her institution and has provided us with additional study samples. We also acknowledge the technical assistance of Miss Jacqueline Thomas. Mrs. Alice Tustion, and Mr. Bruce Geller and the nursing care provided by the staff of the Clinical Research Center.

18. Dr. Frens is the recipient of National Institutes of Health Fellow ship SF1tNS2579.

19. These studies were supported by the Eleanor Rouseselt Cancer Fund of the United States Department of Ifealth. Education and Welfare, Washington. D).C.. and by Clinical Research Center Grant RR-(0)(n)t. Training Gram 511-NS-5503, and Research Grants 571-NS-53(19 and $11-0.4955$ of the National Institutes of llealth. Bethesda, Maryland.

20. Recuests for reprints should be addressed to: D). M1. Williams, M. D). Department of Medicinc. University of Utah. So North Medical Drive, Salt Lake City, Utah $8+132$ (USA).

21. Received for publication July 25. 1976

22. Accepted for puthication November 18. 1976. 